Joanna E. Utkin

Szkoła Główna Handlowa w Warszawie e-mail: jutkin@sgh.waw.pl

ORCID 0000-0001-7446-1254

DOI: 10.15290/mhi.2019.18.02.04

\title{
Potomkowie kupca Wołowskiego - prawnicy, powstańcy w XIX stuleciu
}

\begin{abstract}
AbstrakT
Celem niniejszego opracowania jest wydobycie z cienia roztaczanego przez Jana Kantego Wołowskiego, najwybitniejszego prawnika o tym nazwisku, postaci dwóch niespokrewnionych $\mathrm{z}$ nim braci Wołowskich, znakomitych adwokatów: Jana Tadeusza i Hieronima. Jan Tadeusz Wołowski miał długi staż zawodowy i był uznawany za wzór adwokata. Hieronim Wołowski, choć ceniony adwokat, krócej należał do palestry, był za to powstańcem listopadowym. Jan Tadeusz i Hieronim Wołowscy byli ciotecznymi braćmi sławnej pianistki Marii Szymanowskiej z Wołowskich, co nie pozostało bez wpływu na ich życiorysy. Jak się natomiast okazało, znanym prawnikiem spokrewnionym z Janem Kantym Wołowskim był Feliks Jeziorański. Wszyscy oni pochodzili z rodzin ochrzczonych frankistów ${ }^{1}$. Mit o istnieniu jednej frankistowskiej rodziny Wołowskich jest sprzeczny z wiedzą zawartą w Wielkiej genealogii Minakowskiego.

Tematem przewodnim opracowania jest przedstawienie dwudziestoletniej kariery zawodowej Hieronima Wołowskiego na tle dziejów jego rodziny. Pokazane jest pochodzenie Hieronima od Franciszka Wołowskiego - kupca korzennego i Teresy

$1 \quad$ T. Jeske-Choiński, Neofici polscy, Sandomierz 2017, s. 63-100: Frankiści stanowili odłam żydowskich kontrtalmudystów, którego przywódcą był żyjący w XVIII w. Jakub Frank. W latach 1759-1760 pół tysiąca jego wyznawców zostało ochrzczonych we Lwowie. Masowo przyjmowali wówczas nazwiska o polskim brzmieniu, nie troszcząc się o ich zróżnicowanie. Najliczniejsi byli Wołowscy. Jeske wymienia też m.in. Jasińskich, Jeziorańskich, Łabęckich. Pewna część ochrzczonych frankistów przyszła z Frankiem do Warszawy.
\end{abstract}


Lanckorońskiej. Tematem towarzyszącym jest połączenie wiedzy o życiu i o karierze słynnego adwokata, Jana Tadeusza Wołowskiego. Wybory życiowe i zawodowe Hieronima były podejmowane pod wpływem rad zawodowych Jana Tadeusza oraz obserwacji jego porażek i sukcesów matrymonialnych. Przypomniane jest też zaangażowanie Hieronima i jego brata Andrzeja w powstanie listopadowe. Na zakończenie zasygnalizowany jest udział dwóch synów Hieronima w powstaniu styczniowym.

\section{Abstract \\ Descendants of Wołowski, the merchant - lawyers, insurgents in the 19th century}

The aim of the presented article is to present the lives of the Wolowski brothers, Jan Tadeusz and Hieronim, and to bring them out of the shadow casted by the most eminent and not related to them Jan Kanty Wołowski. Jan Tadeusz Wołowski had a long professional career and was recognized as a model barrister. Hieronim Wołowski had shorter professional practice as a lawyer, but was also a November insurgent. Jan Tadeusz and Hieronim Wołowski were cousins of the famous pianist Maria Szymanowska née Wołowska, what definitely affected their lives. As it turned out, the known lawyer Feliks Jeziorański was related to Jan Kanty Wołowski. They all descended from the baptized Frankists families ${ }^{2}$. The myth of the existence of one Frankist Wołowski family is contrary to the information presented in Minakowski's Great Genealogy.

The leading subject of this study is to present the twenty years of the professional career of Hieronim Wołowski against the background of his family's history. It shows the descent of Hieronim from Franciszek Wołowski, the spice merchant, and Teresa Lanckorońska. The secondary subject is to spread knowledge about the life and career of the famous advocate, Jan Tadeusz Wołowski. Hieronim's life and professional choices were influenced by Jan Tadeusz's vocational advice and observation of his matrimonial failures and successes. The involvement of Hieronim and his brother Andrzej in the November Uprising is also recalled. Finally, the participation of two sons of Hieronim in the January Uprising is mentioned.

Słowa kluczowe: Królestwo Polskie, kariery i rodziny prawników

Key words: Kingdom of Poland/Congress Poland, careers and families of lawyers

2 Ibidem, s. 63-100: Frankists constituted a Jewish branch negating Talmud, led by Jacob Frank who lived in the 18th century. In the years 1759-1760, half a thousand of his followers were baptized in Lviv. They adopted Polish-sounding names on a mass scale, not caring about their diversity. The most numerous were Wołowscy, Jeske also mentions adopted surnames such as: Jasiński, Jeziorański, Łabęcki. Some of the baptized Frankists came to Warsaw together with Frank. 


\section{Przodkowie Hieronima Wołowskiego i prawnicy $\mathrm{z}$ dalszej rodziny}

Dzieje kupieckiej rodziny Wołowskich nie są tak znane, jak dzieje piwowarskich rodzin o tym nazwisku. Mimo niższej pozycji majątkowej, przedstawiciele rodziny kupieckiej mieli określone poglądy polityczne, a wywodzący się z niej kawalerowie wstępowali do oddziałów powstańczych, zarówno w czasie powstania listopadowego, jak i styczniowego. Centralną postacią opracowania jest Hieronim Napoleon Wołowski, syn kupca Józefa, prawnik, ojciec dwóch powstańców styczniowych. Urodzony w czasach marszu armii francuskiej na wschód Europy, naznaczonych zwycięstwem pod Jeną, dostał na chrzcie imiona dwóch braci Bonaparte: króla Westfalii Hieronima i cesarza Francji Napoleona. Później Wołowski używał pierwszego imienia.

Hieronim Wołowski (dwóch imion: Hieronim Napoleon) urodził się w Płocku w 1806 r. Był synem Józefa Wołowskiego i Marianny z Jasińskich Wołowskiej ${ }^{3}$. Józef Wołowski (dwóch imion: Józef Kazimierz) był kupcem. Urodził się w Warszawie w 1771 r., tam też zmarł ${ }^{4}$. Józef z rodziną mieszkał w Płocku ponad dwadzieścia lat. Tam urodzili się bracia Hieronima: Andrzej w 1803 r. ${ }^{5}$, Franciszek (trzech imion: Franciszek Ksawery Józef) w 1810 r. ${ }^{6}$ i Józef jr w 1815 r. ${ }^{7}$, a być może również siostry: Karolina Emilia w 1800 r. i Kazimiera w 1802 r. Później każda z nich była po mężu Kozicka ${ }^{8}$. W 1818 r. Józef Wołowski był deputowanym na sejm z okręgu miasta Płocka' ${ }^{9}$. Warszawa i Płock leżą nad Wisłą, która była rzeką spławną. Kupiec Józef Wołowski musiał wykorzystywać ten szlak wodny do transportu towaru.

Z aktu zgonu Adama Wołowskiego, brata Józefa - kupca wynika, że ich ojciec, Franciszek Wołowski był urodzony w 1745 r., a w 1808 r. mieszkał w Warszawie, gdzie przy ul. Elektoralnej miał swój sklep z towarami korzennymi ${ }^{10}$. Według Wielkiej genealogii Minakowskiego wymieniony Franciszek Wołowski był ochrzczonym frankistą ${ }^{11}$.

3 Akt zgonu: Warszawa, św. Andrzej, 322/1848, http://metryki.genealodzy.pl/metryka.php?ar=1\&zs= 0159d\&sy=1848\&kt=3\&plik=319-322.jpg\#zoom =1\&x=2667\&y=1471 (12.05.2019).

4 Akt zgonu: Warszawa, św. Andrzej,169/1835,http://metryki.genealodzy.pl/metryka.php?ar=1\&z$\mathrm{s}=0159 \mathrm{~d} \& \mathrm{sy}=1835 \& \mathrm{kt}=3 \& \mathrm{plik}=167-170 . j p g \#$ zoom $=1 \& \mathrm{x}=2627 \& \mathrm{xy}=147$ (12.05.2019).

5 R. Gerber, Studenci Uniwersytetu Warszawskiego 1808-1831. Słownik biograficzny, Wrocław 1977, s. 339.

6 Akt małżeństwa: Płock, 22/1836,https://szukajwarchiwach.pl/50/155/0/-/20/\#tabSkany (15.05.2019).

7 Akt zgonu: Warszawa, św. Jan, 522/1832,http://metryki.genealodzy.pl/metryka.php?ar=1\&zs=0161d \&sy $=1832 \& k \mathrm{kt}=3 \&$ plik=520-525.jpg $\#$ zoom $=1 \& \mathrm{x}=563 \& \mathrm{y}=2108(12.05 .2019)$.

8 Karolina Emilia Wołowska, [w:] M.J. Minakowski, Wielcy.pl, https://wielcy.pl/wgm/?m=NG\&t=PN\& $\mathrm{n}=12.110 .187$ (12.05.2019).

9 M.Karpińska, Senatorowie, posłowie i deputowani Księstwa Warszawskiego i Królestwa Polskiego, Warszawa 2002, s. 95.

10 Akt zgonu: Warszawa, ASC Cyrkut IV, 156/1808,https://szukajwarchiwach.pl/72/186/0/-/3/skan/ful1/3gRPVgLVOLmk7IihjwXzfw (12.05.2019).

11 T. Jeske-Choiński, op. cit., s.46. 
Pokrewieństwo Hieronima Wołowskiego z wieloma prawnikami o tym nazwisku, jak również powinowactwo z Janem Kantym Wołowskim żyjącym w latach 1803-1864, wynika z ich koligacji z Józefem Lanckorońskim, ochrzczonym frankistą i Klarą Matuszewską. Józef i Klara Lanckorońscy mieli siedmioro dzieci ${ }^{12}$. Najstarsza córka, Teresa, była żoną Franciszka Wołowskiego - kupca korzennego i matką Józefa Wołowskiego ${ }^{13}$. Najmłodsza córka, Elżbieta, była żoną Ludwika Wołowskiego, jednego z synów Franciszka Salomona Łukasza, przywódcy warszawskich frankistów. Jedna ze średnich córek, Marianna, była żoną Ignacego Jeziorańskiego, przy czym dwóch starszych synów tej pary miało związki z rodziną Jana Kantego Wołowskiego ${ }^{14}$; ich trzeci syn był przodkiem słynnego kuriera, Jana Nowaka-Jeziorańskiego ${ }^{15}$. Wymienione panny Lanckorońskie miały wnuków, którzy kończyli studia prawnicze, wielu z nich robiło kariery prawnicze, a niektórzy zdobyli sławę.

Teresa z Lanckorońskich Wołowska miała oprócz Józefa i dwóch innych synów dwie córki, które zostały korzystnie wydane za mąż. Starsza córka Barbara była żoną Franciszka Ksawerego Wołowskiego - piwowara i matką sławnej pianistki Marii Szymanowskiej ${ }^{16}$. Franciszek - piwowar był zaś synem Franciszka Salomona Łukasza Wołowskiego. Młodsza córka Teresy, Ewa została wydana za mąż za Antoniego Łabęckiego, urzędnika, polityka, wykładowcę prawa i znanego adwokata ${ }^{17}$.

Elżbieta z Lanckorońskich Wołowska była matką ośmiorga Wołowskich, z których troje weszło do historii środowiska prawników. Najstarsza z nich, Tekla Wołowska została żoną Franciszka Eliasza Wołowskiego, nabywcy majątku na Kaskach, który po ukończeniu studiów prawniczych za granicą pracował w warszawskich sądach i urzędach, a także zajmował się polityką ${ }^{18}$. Był deputowanym $\mathrm{z}$ okręgu warszawskiego na sejmy w $1825 \mathrm{r}$. i w $1830 \mathrm{r}^{19}{ }^{19}$ oraz aktywnie uczestniczył w obradach sejmu powstańczego. Wyemigrował do Francji. Jeden z jego synów, Ludwik Wołowski zyskał sławę jako francuski prawnik

12 Adam Wołowski, [w:] M.J. Minakowski, Wielcy.pl, https://wielcy.pl/wgm/?m=NG\&t=PN\&n=sw. 717949 (12.05.2019).

13 Akt zgonu: Warszawa, św. Andrzej, 169/1835, op. cit.

14 Adam Wołowski, op. cit.

15 Zdzisław Antoni Jeziorański „Jan Nowak”, [w:] M.J. Minakowski, Wielcy.pl, https://wielcy.pl/wgm/? $\mathrm{m}=\mathrm{NG} \& \mathrm{t}=\mathrm{PN} \& \mathrm{n}=\mathrm{sw} .155427$ (27.05.2019).

16 T. Syga, S. Szenic, Maria Szymanowska i jej czasy, Warszawa 1960, s. 493; Karolina Emilia Wołowska, op. cit. O. Tokarczuk napisała w Księgach Jakubowych..., str. 62, że Franciszek ożenił się z Barbarą dla bułek.

17 K. Pol, Poczet prawników polskich, wyd. 2 przejrzał i uzupełnił A. Redzik, Warszawa 2011, s. 54; L. Sługocki, Łabęcki Antoni, [w:] Słownik biograficzny adwokatów polskich, t. 1, Warszawa 1980, s. $230-233$.

18 W. Witkowski, Aleksander This i Jan Kanty Wołowski wybitni prawnicy Królestwa Polskiego, Lublin 2001, s. 43.

19 M. Karpińska, op. cit., s. 95. 
i ekonomista ${ }^{20}$. Brat Tekli, Adam Alfons Wołowski był sędzią w radomskim trybunale cywilnym, następnie w sądzie kryminalnym płockim, a na koniec w sądzie apelacyjnym Królestwa Polskiego ${ }^{21}$. Najmłodsza z dzieci Elżbiety Henrietta $\mathrm{z}$ Wołowskich primo voto Jeziorańska była żoną Jana Kantego Wołowskiego, najwybitniejszego prawnika o tym nazwisku ${ }^{22}$.

Najstarszy syn Marianny z Lanckorońskich Jeziorańskiej, Józef, został mężem Henrietty Wołowskiej. Był o tyle lat starszy od poślubionej kuzynki, że mógłby być jej ojcem. Jednak ojcem w ogóle być chyba nie mógł i małżeństwo przestało istnieć. Henrietta wyszła powtórnie za mąż za Jana Kantego Wołowskiego. W tym związku przeżyła wiele lat, towarzyszyła mężowi w czasach gdy robił karierę adwokacką, a potem prokuratorską. Po śmierci Henrietty, Jan Kanty był parodniowym ministrem sprawiedliwości, lecz przede wszystkim organizował wydział prawa i przygotowywał program wykładów dla powstającej w Warszawie Szkoły Głównej. Po rewizjach ujawniających materiały o antyrosyjskiej treści, Wołowski został aresztowany, a następnie zesłany w głąb Rosji. Na zesłaniu pisał Kurs kodeksu cywilnego. Zmarł w Rosji w $1864 \mathrm{r}^{23}$.

Drugi syn Marianny z Lanckorońskich Jeziorańskiej, Michał, został mężem siostry Jana Kantego, Karoliny Anny Wołowskiej. Ich starszy syn Feliks (trzech imion: Feliks Ignacy Paweł) Jeziorański, urodzony na prowincji, a wykształcony w Warszawie, $\mathrm{w}$ zakresie gimnazjum $\mathrm{z}$ dwuletnim kursem prawa, piął się po szczeblach kariery sądowniczej, a równocześnie pisał prace z teorii prawa ${ }^{24}$. Po śmierci wuja, Jana Kantego, uzupełnił i wydał Kurs kodeksu cywilnego. Później opublikował wiele własnych opracowań prawniczych. Drugi wuj Feliksa Jeziorańskiego, Franciszek Wołowski, urodzony w 1805 r. też skończył prawo, jednak po upadku powstania listopadowego wyemigrował i nie pracował w zawodzie prawnika $^{25}$. Według Wielkiej genealogii Minakowskiego, Jan Kanty Wołowski, syn Pawła i Marianny z Szymanowskich, miał łącznie czworo rodzeństwa: prócz Karoliny Anny i Franciszka byli to Adam Jakub Michał Wołowski i Natalia Wolowska ${ }^{26}$.

Podsumowując, dziadek Hieronima Wołowskiego od strony ojca, Franciszek Wołowski - kupiec korzenny, urodzony w 1745 r., należał do grona Wołowskich - frankistów, którzy po przyjęciu chrztu w kościele rzymskokatolickim zamieszkali w Warszawie, jednak nie był synem ich przywódcy, Franciszka Salomona Łukasza Wołowskiego żyjącego w latach 1732-1813. Natomiast pokrewieństwo z potomkami synów przywódcy, Ludwika i Franciszka - piwowara zapewniły

20 W. Witkowski, op. cit., s. 43.

21 Ibidem, s. 46.

22 Jan Kanty Wołowski, [w:] M. J. Minakowski, Wielcy.pl, https://wielcy.pl/wgm/?m=NG\&t=PN\&n =sw.206242 (12.05.2019).

23 W. Witkowski, op. cit., s. 218-228.

24 K. Pol, op. cit., s. 219-226.

25 R. Gerber, op. cit., s. 239.

26 Jan Kanty Wołowski, op. cit. 
babka Hieronima ze strony ojca, Teresa Lanckorońska i siostra ojca Hieronima, Barbara Wołowska. Ustalenie rodziców Hieronima Wołowskiego, jakie podano w słowniku biograficznym studentów Uniwersytetu Warszawskiego, a powtórzono w Słowniku biograficznym adwokatów polskich, było błędne ${ }^{27}$.

Matka Hieronima, Marianna z Jasińskich Wołowska urodzona w 1773 r., pochodziła z województwa lubelskiego. Była córką Józefa Jasińskiego i Justyny z Wołowskich. Rodzice Marianny zmarli w Warszawie ${ }^{28}$. Według Wielkiej genealogii Minakowskiego rodzicami Józefa Jasińskiego byli Szymon Jasiński ochrzczony frankista i Rozalia. Przodkowie Justyny Wołowskiej, ani Rozalii nie są znani ${ }^{29}$. Umierając w 1831 r. matka Hieronima pozostawiła po sobie, zgodnie z treścią cytowanego aktu zgonu, owdowiałego męża i dziewięcioro dzieci: siedmiu synów i dwie córki. Świadkami zejścia Marianny Wołowskiej byli jej mąż i syn Hieronim, którzy wiedzieli co podpisują. Wśród zidentyfikowanych braci Hieronima Wołowskiego najstarszy był Fryderyk (dwóch imion: Jerzy Fryderyk) - burmistrz w Serocku ${ }^{30}$, a najmłodszy - Józef jr zmarły jako siedemnastolatek $^{31}$. Losy pozostałych znanych braci tworzyły tło życia Hieronima. Do tej pory nie jest znana tożsamość jednego z braci Hieronima. Tradycja kupiecka rodziny sugeruje, że mógł to być starszy brat, który pozostał w Płocku, gdzie prowadził zainicjowane przez ojca interesy, przejęte następnie przez młodszego brata, Franciszka - subiekta handlu, który z kolei wrócił do Płocka po śmierci ojca w 1835 r. i został kupcem ${ }^{32}$.

\section{Jan Tadeusz i Andrzej - bracia Hieronima}

Hieronim był jednym z młodszych dzieci kupca Józefa Wołowskiego. Dokonywał wyborów życiowych w cieniu karier i porażek wykształconych starszych braci: prawnika Jana Tadeusza i lekarza Andrzeja, jednocześnie w okresie zubożenia swego ojca. Hieronim skończył studia prawnicze i został adwokatem jak Jan Tadeusz, wstąpił do wojska w czasie powstania listopadowego jak Andrzej, lecz przeciwnie do Jana Tadeusza nie oświadczał się pannie ze środowiska rodzinnego.

27 R. Gerber, op. cit., s. 240; J. Romański, Hieronim Wołowski, [w:] Słownik biograficzny adwokatów polskich, t. 1, Warszawa 1983, s. 477.

28 Akt zgonu: Warszawa, św. Jan, 357/1831, https://szukajwarchiwach.pl/72/161/0/-/6/skan/full/yDM 4UFgefsK_L2rJwC6e5g (12.05.2019).

29 Karolina Emilia Wołowska, op. cit.

30 Akt urodzenia: Warszawa, św. Jan, 542/1841, http://metryki.genealodzy.pl/metryka.php?ar=8\&zs=9 $233 \mathrm{~d} \& \mathrm{sy}=135 \& \mathrm{kt}=3 \& \mathrm{skan}=539-542 . j p g \# z o o m=1 \& \mathrm{x}=1675 \& \mathrm{xy}=1294(12.05 .2019)$.

31 Akt zgonu: Warszawa, św. Jan, 522/1832, op. cit.

32 Akt zgonu: Warszawa, św. Andrzej,169/1835, op. cit.; Akt zgonu: Płock, par. rzym.kat. św. Bartłomieja, 122/1850, Archiwum Państwowe w Płocku. 
Dokonania zawodowe Jana Tadeusza Wołowskiego są znane ${ }^{33}$. Warto jednak uporządkować je chronologicznie i uzupełnić faktami z życia osobistego. Te zaś wiążą się z rodziną siostry ojca, Barbary z Wołowskich i jej męża Franciszka Wołowskiego - piwowara. Najwięcej sławy klanowi Wołowskich przysporzyła córka tej pary - pianistka Maria Szymanowska. Jej europejskie sukcesy artystyczne nie poszły w zapomnienie dzięki małżeństwu córki Celiny z Adamem Mickiewiczem. W trasach koncertowych artystce zawsze towarzyszył któryś brat i piękna siostra Kazimiera (dwóch imion: Kazimiera Fryderyka) ${ }^{34}$.

Jan Tadeusz Wołowski, syn Józefa i Marianny z Jasińskich, urodził się w Warszawie w 1794 r. Studiował w Szkole Prawa Księstwa Warszawskiego, w której wykładał m.in. jego wuj, Antoni Łabęcki . Wuj Łabęcki należący do ekipy prawników ministra sprawiedliwości w Księstwie Warszawskim, Feliksa Łubieńskiego, brał udział w tłumaczeniu Kodeksu Napoleona ${ }^{35}$. Jan Tadeusz po odbyciu studiów wyjechał do Płocka, gdzie wówczas mieszkali jego rodzice. Był asesorem przy Trybunale Pierwszej Instancji w Płocku. Po przejściu do adwokatury już w 1824 r. został adwokatem przy Sądzie Apelacyjnym Królestwa Polskiego, a w 1826 r. - mecenasem przy Sądzie Najwyższej Instancji Królestwa Polskiego ${ }^{36}$.

Życie osobiste Jana Tadeusza nie było tak udane jak zawodowe. Gdy w $1826 \mathrm{r}$. Maria Szymanowska wróciła z siostrą Kazimierą do Warszawy, gdzie bawiły aż do 1827 r., Jan Tadeusz oświadczył się Kazimierze. Nie został przyjęty. Latem 1828 r. Jan Tadeusz ożenił się z Ludwiką This, siostrą Aleksandra Thisa, pierwszego bohatera książki Wojciecha Witkowskiego. W 1832 r. urodził się ich syn, Bolesław Kazimierz Aleksander Wołowski, który umarł jeszcze tego samego roku. Ludwika $\mathrm{z}$ Thisów Wołowska zmarła w 1834 r. ${ }^{37}$ Rok później zmarł ojciec Jana Tadeusza, a pięć dni po jego śmierci zmarła ciotka, Barbara Wołowska ${ }^{38}$. Jan Tadeusz Wołowski występuje we wszystkich cytowanych aktach zgonu jako świadek zejścia wymienionych zmarłych. Kuzynka, a zarazem druga żona Jana Tadeusza, Kazimiera napisała wiele lat później: „zapragnął raz jeszcze mojej ręki. Objawione mi życzenie matki mojej, już natenczas umierającej, skłoniło mnie do przyjęcia go za męża"39. W latach 1836-1842 Kazimiera powiła pięcioro dzieci,

33 K. Pędowski, Wołowski Jan Tadeusz, [ w:] Słownik biograficzny adwokatów polskich, t. 1, Warszawa 1883, s. 480-481; W. Witkowski, op. cit., s. 45, 50.

34 T. Syga, S. Szenic, op. cit.; Karolina Emilia Wołowska, op. cit.

35 K. Pol, op. cit., s. 52-54; L. Sługocki, Łabęcki Antoni, [w:] Słownik biograficzny adwokatów polskich, t. 1, Warszawa 1981, s. 230-233.

36 W. Witkowski, op. cit., s. 35.

37 Ludwika Nowopolski-Thisz h. Rycerzosław, [w:] M.J. Minakowski, Wielcy.pl, https://wielcy.pl/wgm/ ? $\mathrm{m}=\mathrm{NG} \& \mathrm{t}=\mathrm{PN} \& \mathrm{n}=\mathrm{sw} .299167,(12.05 .2019)$.

38 Akt zgonu: Warszawa, św. Andrzej,169/1835,op.cit.; Akt zgonu: Warszawa, św. Andrzej, 179/1835, http://metryki.genealodzy.pl/metryka.php?ar=1\&zs=0159d\&sy=1835\&kt=3\&plik=179-182. jpg\#zoom $=1 \& \mathrm{x}=538 \& \mathrm{y}=240(12.05 .2019)$.

39 T. Syga, S. Szenic, op. cit., s. 457. 
z których dwoje nie dożyło chrztu, a dwoje innych ochrzczonych zmarło w dzieciństwie $^{40}$. Świadek, który pamiętał Kazimierę - wdowę mówił, że poświęciła się ona wychowaniu swej jedynej córki Celiny, zmarłej panną ${ }^{41}$. Jednym ze świadków zgłaszających w 1840 r. narodziny tej córki Jana Tadeusza i Kazimiery był Hieronim Wołowski.

Jan Tadeusz Wołowski jako adwokat specjalizował się w sprawach cywilnych dotyczących najczęściej odwołań od decyzji sądów niższych instancji odnośnie do sukcesji ${ }^{42}$. W przypadku spraw o ciekawszym aspekcie prawnym publikował swoje wystąpienia procesowe. Wydano drukiem około dwudziestu jego pism, przy czym były one bardzo obszerne, a jednocześnie rzetelne zawodowo ${ }^{43}$. W dwóch udokumentowanych sporach reprezentował sukcesorów występujących przeciwko klientom Jana Kantego Wołowskiego, mianowicie przeciwko spadkobiercom Jakuba Pisarzewskiego, a także przeciwko familii Wielopolskich występującej o odzyskanie dóbr z ordynacji myszkowskiej ${ }^{44}$. Najbardziej znana była jednak obrona księdza Dembka przed Sądem Sejmowym. Ksiądz Konstanty Tomasz Dembek, żyjący w latach 1772-1828, był profesorem teologii na Uniwersytecie Warszawskim i dyrektorem drukarni rządowej. Należał też do nielegalnego Towarzystwa Patriotycznego. Został aresztowany i w 1827 r. oskarżony wraz z Sewerynem Krzyżanowskim i innymi aktywistami Towarzystwa o zbrodnię stanu. W wyniku obrony przeprowadzonej przez Jana Tadeusza Wołowskiego księdzu zasądzono tylko trzy miesiące więzienia za udział w tajnym stowarzyszeniu. Zaangażowanie mecenasa $\mathrm{w}$ tę sprawę miało jeszcze inny wymiar: zarówno obrońca, jak i podsądny należeli wcześniej do loży wolnomularskiej „Świątynia Izis", w której obrońca był członkiem pierwszego stopnia, a podsądny miał wysoki stopień wtajemniczenia. Mimo sukcesu obrońcy, ksiądz zmarł w więzieniu przed zatwierdzeniem wyroku ${ }^{45}$. Druga wyjątkowa rola obrońcy wynikała z mianowania przez Komisję Rządową Sprawiedliwości Jana Tadeusza Wołowskiego adwokatem z przymusu przy Najwyższym Sądzie Kryminalnym

40 Akturodzenia: Warszawa, św. Andrzej, 333/1836,http://metryki.genealodzy.pl/metryka.php?ar=1\&z$\mathrm{s}=0159 \mathrm{~d} \& \mathrm{sy}=1836 \& \mathrm{kt}=1 \&$ plik=331-334.jpg\#zoom $=1 \& \mathrm{x}=2639 \& \mathrm{y}=404 \quad(12.05 .2019) ;$ Akt zgonu: Warszawa, św. Andrzej,156/1837,http://metryki.genealodzy.pl/metryka.php?ar=1\&zs=0159d\&sy$=1837 \& \mathrm{kt}=3 \& \mathrm{pplik}=155-158$.jpg\#zoom $=1 \& \mathrm{x}=938 \& \mathrm{y}=2331 \quad$ (12.05.2019); Akt urodzenia: Warszawa, Nawiedzenie NMP, 881/1838, http://metryki.genealodzy.pl/metryka.php?ar=1\&zs=0160d\&sy$=1838 \mathrm{a} \& \mathrm{kt}=1 \& \mathrm{kplik}=879-882 . j p g \# \mathrm{zoom}=1 \& \mathrm{x}=2512 \& \mathrm{ky}=127$ (12.05.2019); Akt urodzenia: $247 / 1840$ Warszawa, św. Andrzej, 247/1840, http://metryki.genealodzy.pl/metryka.php?ar=1\&zs=0159d\&sy$=1840 \& \mathrm{kt}=1 \&$ plik=247-250.jpg\#zoom $=1 \& \mathrm{x}=472 \& y=175$ (12.05.2019); Akt zgonu: Warszawa, św. Andrzej, 290/1842, http://metryki.genealodzy.pl/metryka.php?ar=1\&zs=0159d\&sy=1842\&kt=3\& plik=287-290.jpg\#zoom=1\&x=2830\&y=1668 (15.05.2019).

41 T. Syga, S. Szenic, op. cit.

42 A. Suligowski, Bibliografia prawnicza polska XIX i XX wieku, Warszawa 1911, s. 33-34.

43 K. Pędowski, op. cit., s. 481.

44 A. Suligowski, op. cit., poz. 549,555,556,563,564,568,570,572; W. Witkowski, op. cit., s. 47.

45 K. Pędowski, op. cit., s. $480-481$; A.Suligowski, op. cit., s. 33 poz. 554 , s. 50 poz. 803; S. Szenic, Cmentarz Powazkowski 1790-1850. Zmarli i ich rodziny, Warszawa 1979, s. 211-212. 
powołanym w Warszawie po upadku powstania listopadowego dla osądzenia jego uczestników. Wołowski bronił przed tym sądem podchorążego Kazimierza Płaczkowskiego ${ }^{46}$.

Zaangażowanie Jana Tadeusza w obronę patriotów przypadało na czasy narzeczeństwa i małżeństwa z Ludwiką z Thisów. W okresie małżeństwa z Kazimierą Fryderyką z Wołowskich, Jan Tadeusz przyjmował dodatkowe funkcje: w 1838 r. był powołany obrońcą przy sądzie konsystorskim w Konsystorzu Generalnym Wyznań Ewangelickich, w 1840 r. został plenipotentem prawnym Księstwa Łowickiego, przy tym w 1842 r. po reorganizacji najwyższej instancji sądowej objął funkcję obrońcy przy Warszawskich Departamentach Rządzącego Senatu ${ }^{47}$.

Jan Tadeusz Wołowski zmarł w 1843 r. w wieku 49 lat. Jego zgon zgłosili w parafii św. Aleksandra brat Hieronim Wołowski i Aleksander Wołowski, brat Kazimiery. Wdowa Kazimiera Wołowska umieściła swój kapitał w rencie dożywotniej. Zmarła w 1888 r. $^{48}$

Drugim bratem, który miał wpływ na życie Hieronima, głównie w okresie powstania listopadowego, był Andrzej. Wybierając zawód lekarza Andrzej poszedł w ślady Stanisława Wołowskiego, syna Barbary i Franciszka - piwowara. Obaj byli lekarzami w wojsku powstańczym, a po upadku powstania wyemigrowali do Francji ${ }^{49}$.

Andrzej Wołowski (dwóch imion: Andrzej Piotr), syn Józefa i Marianny z Jasińskich, urodził się w Płocku 30 listopada 1803 r. W latach 1821-1825 studiował na sekcji medycyny wyższej Wydziału Lekarskiego Uniwersytetu Warszawskiego uzyskując stopień magistra medycyny i chirurgii. Gdy zapisywał się na studia, złożył kwit $\mathrm{z}$ opłaty czesnego ${ }^{50}$. W tym czasie rodzina Józefa Wołowskiego mieszkała już z powrotem w Warszawie, choć starsza siostra Andrzeja, Karolina Wołowska, została wydana za mąż w 1820 r. jeszcze w Płocku ${ }^{51}$. W latach 1827-1830 Andrzej służył w wojsku jako lekarz: najpierw w Szpitalu Głównym Wojskowym, następnie w batalionie Pierwszej Kompanii Artylerii Pieszej Pozycyjnej. We wrześniu 1830 r. został zwolniony z wojska ${ }^{52}$.

Andrzej Wołowski wstąpił do wojska powstańczego dnia 17 lutego $1831 \mathrm{r}$. Był lekarzem sztabowym szpitala wojskowego i Drugiego Pułku Mazurów. Był odznaczony Krzyżem Virtuti Militari ${ }^{53}$. W październiku 1831 r. wyszedł do

46 T. Kędzierski, Proces „dyktatora Nocy Listopadowej” - Piotra Wysockiego, „Palestra” 1977, nr 21/11 (239), s. 49.

47 W. Witkowski, op. cit., s. 45.

48 Akt zgonu: Warszawa, św. Aleksander, 334/1843, https://szukajwarchiwach.pl/72/162/0/-/21/skan/ full/mxqt0W5gYehvn-QM0QRWxw (12.05.2019); T. Syga, S .Szenic, op. cit., s. 457, 493.

49 R. Gerber, op. cit., s. 339.

50 Ibidem.

51 Karolina Emilia Wołowska, op. cit.

52 R. Gerber, op. cit., s. 339.

53 Ibidem. 
Prus z Korpusem gen. Macieja Rybińskiego ${ }^{54}$ i udał się na emigrację do Francji. W 1832 r. zwalczał w Paryżu epidemię cholery, za co otrzymał Krzyż Legii Honorowej. W paryskim czasopiśmie medycznym „Revue Medicale” ogłosił komunikat o cholerze morowej. Po powrocie w 1832 r. do Królestwa Polskiego prowadził w latach 1833-1836 praktykę w Brześciu Kujawskim, a w późniejszych latach praktykował w Warszawie. Przez dziesięć lat kierował honorowo Szpitalem Towarzystwa Dobroczynności, za co otrzymał Krzyż św. Stanisława ${ }^{55}$.

\section{Hieronim Wołowski - kariera i rodzina}

Hieronim Wołowski ma trzy swoje biogramy: w słowniku studentów Uniwersytetu Warszawskiego, w słowniku biograficznym adwokatów polskich oraz w słowniku biograficznym płocczan ${ }^{56}$. Jednak wbrew podanym tam informacjom był on synem Józefa Wołowskiego - kupca, a nie Franciszka - piwowara. Prawnicza kariera zawodowa Hieronima przypadała na czasy, gdy w Królestwie Polskim obowiązywał Kodeks Karzący z 1818 r. oparty na francuskim podziale przestępstw oraz Kodeks Cywilny z 1825 r. ${ }^{57}$.

Józef Wołowski z rodziną mieszkał to w Warszawie, to w Płocku. Hieronim rozpoczął studia na sekcji prawa Wydziału Prawa i Administracji Uniwersytetu Warszawskiego w październiku 1825 r. W tym czasie rodzice znów mieszkali w Płocku. Musieli mieć kłopoty finansowe - zamiast kwitu opłaty za studia Hieronim złożył świadectwo ubóstwa. Zapewne mieszkał w czasie studiów u Jana Tadeusza, korzystał z jego wskazówek zawodowych i kibicował mu w sprawach matrymonialnych. W 1828 r. uzyskał stopień magistra prawa. W końcu lipca tego roku Jan Tadeusz ożenił się z Ludwiką This ${ }^{58}$. Podobnie jak szwagier Aleksander This, Hieronim miał zostać aplikantem, a po zdaniu odpowiedniego egzaminu podjąć pracę inkwirenta ${ }^{59}$. W międzyczasie, rodzice Hieronima $\mathrm{z}$ młodszymi braćmi, Franciszkiem i Józefem, przenieśli się z powrotem do Warszawy. Zamieszkali wówczas przy ul. Bednarskiej 2688. Adres na Powiślu, wymieniony w akcie zgonu matki Hieronima, może świadczyć o osobistym nadzorze ojca nad przeładunkiem towaru spławianego barką po Wiśle.

Po wybuchu powstania listopadowego, Hieronim uznał za swojego mentora Andrzeja, byłego lekarza wojskowego. W kwietniu 1831 r., gdy zmarła ich matka, Marianna Wołowska, Hieronim podpisany na akcie zgonu jako świadek

54 A .Taras, Anatomia nienawiści. Stosunki polsko - rosyjskie XVIII-XX w., Warszawa 2015, s. 231.

55 R. Gerber, op. cit., s. 339.

56 Ibidem, s. 240; J. Romański, op. cit.; A. J. Papierowski, J. Stefański, Płocczanie znani i nieznani. Słownik biograficzny, Płock 2002, s. 645.

57 E.Kaczyńska, Ludzie ukarani. Więzienia i system kar w Królestwie Polskim 1815-1914, Warszawa 1989, s. 42,46 .

58 Ludwika Nowopolski-Thisz h. Rycerzosław, op. cit.

59 W. Witkowski, op. cit., s. 33. 
zejścia, był audytorem Drugiego Pułku Mazurów ${ }^{60}$. Audytor był drugim po kwatermistrzu funkcjonariuszem średniego sztabu pułku. Drugi Pułk Mazurów był ochotniczym mazowieckim pułkiem jazdy, który w lutym 1831 r. przeszedł na etat Komisji Rządowej Wojny. Pułk brał udział w bitwach i potyczkach powstania listopadowego poczynając od Grochowa (25 lutego 1831 r.), a kończąc na Rypinie (3 października 1831 r. ${ }^{61}$. Po upadku powstania Hieronim przebywał na emigracji ${ }^{62}$. Jednak repatriował się wystarczająco szybko, aby jako kawaler o ustabilizowanej sytuacji bytowej mógł stanąć na ślubnym kobiercu już jesienią $1832 \mathrm{r}$. Stabilizacja polegała na stałym zatrudnieniu na stanowisku inkwirenta ${ }^{63}$ przy Sądzie Policji Poprawczej. Poniższe fakty przeczą informacji o kilkuletnim pobycie Hieronima Wołowskiego na emigracji we Francji zamieszczonej w Słowniku biograficznym adwokatów polskich ${ }^{64}$.

29 października 1832 r. Hieronim Napoleon Wołowski zawarł religijne małżeństwo z Balbiną Teodozją Nelską. Ślub odbył się w rzymskokatolickiej parafii w Brześciu Kujawskim. Osiemnastoletnia Balbina była urodzoną w Brześciu córką Jana Nelskiego, obrońcy Sądu Pokoju powiatu brzeskiego i jego małżonki Apolonii ze Zgliczyńskich, zamieszkałych w Brześciu. Hieronim był zamieszkałym w Brześciu inkwirentem przy Sądzie Policji Poprawczej Wydziału Brzesko-Kujawskiego. Świadkami byli: Andrzej Wołowski, magister medycyny i chirurgii, brat nowo zaślubionego i Tomasz Szaniawski - pisarz wymienionego sądu, obaj w Brześciu zamieszkali ${ }^{65}$.

W Brześciu z tego związku urodziło się przynajmniej dwoje starszych dzieci: w 1834 r. - Ludwik Dionizy Wołowski, a w 1835 r. - Leokadyna Marianna Wołowska ${ }^{66}$. Rodzice chrzestni Leokadyny: Anna Nelska - młodsza siostra Balbiny i Józef Grodecki - inkwirent Sądu Policji Poprawczej Wydziału Brzeskiego wzięli ślub w 1838 r. ${ }^{67}$ Starsza siostra Balbiny, Eleonora Nelska wyszła za mąż za Jana Stanisława Święcickiego, właściciela majątku Słone w pobliskiej parafii Wieniec. Jednym ze świadków tego małżeństwa zawartego w Brześciu w styczniu 1837 r. był Andrzej Wołowski, magister medycyny i chirurgii, lekarz

60 Akt zgonu: Warszawa, św. Jan, 357/1831, op. cit.

61 Drugi Pułk Mazurów, https://pl.wikipedia.org/wiki/2_Pu\%C5\%82k_Mazur\%C3\%B3w (12.05.2019).

62 R. Gerber, op. cit., s. 240.

63 Inkwirent - sędzia śledczy, przyp. aut.

64 J. Romański, op. cit.

65 Akt małżeństwa: Brześć Kujawski, 60/1832, https://genealogiawarchiwach.pl/\#query.query=60\%2 52F1832\&query.city=Brze $25 \mathrm{C} 5 \% 259 \mathrm{~B} \% 25 \mathrm{C} 4 \% 2587+$ Kujawski\&query.page $=1$ \&query.sugge stion $=$ false \&query.thumbnails=false\&query.facet $=$ false\&query.sortMode=DEFAULT\&moda $\mathrm{l}=256368355 \&$ goComments=false\&searcher $=$ big $(12.05 .2019)$.

66 Akty urodzenia: Brześć Kujawski, par. rzym.-kat., 133/1834 i 38/1835, Archiwum Państwowe w Toruniu, Oddział we Włocławku.

67 Akt małżeństwa: Brześć Kujawski, par. rzym.-kat., 5/1838, Archiwum Państwowe w Toruniu, Oddział we Włocławku. 
wolno praktykujący ${ }^{68}$. Można przypuszczać, że Balbina powierzyła szwagrowi rolę swata swojej starszej siostry - z porady lekarza korzystało także ziemiaństwo. Andrzej nie miał już wtedy stałej praktyki w Brześciu. Wydaje się, że nie tylko Andrzej, a także Hieronim już w 1837 r. wyjechali z Brześcia. Być może Balbina Wołowska $\mathrm{z}$ dziećmi mieszkała jeszcze przez parę lat w swoim rodzinnym mieście.

Po roku 1837 z powodu wakatów w sądownictwie zliberalizowano kryteria nominacji, np. aplikantom stworzono możliwość mianowania patronami, zaś odpowiedni staż pracy mógł wystarczyć, aby z patrona przejść na adwoka$\operatorname{ta}^{69}$. Zapewne Jan Tadeusz podzielił się $z$ Hieronimem wiedzą o przyspieszonej ścieżce awansu, a ten po pięciu latach pracy na jednym stanowisku inkwirenta skwapliwie z tej możliwości skorzystał. Mianowicie, Hieronim w 1839 r. został mianowany przez Komisję Rządową Sprawiedliwości patronem przy Trybunale Cywilnym Pierwszej Instancji guberni mazowieckiej w Warszawie, a w $1841 \mathrm{r}$. Rada Administracyjna mianował go adwokatem Sądu Apelacyjnego Królestwa Polskiego $^{70}$. Hieronim w 1844 r. opublikował, naśladując Jana Tadeusza, swoją Odpowiedź ze strony sukcesorów Teodora Chrząstowskiego na skarge Antoniego Morzyckiego ${ }^{71}$, lecz była to jedyna jego publikacja. Przez pewien czas Hieronim pełnił obowiązki radcy prawnego Zarządu Komunikacji Lądowych i Wodnych na XIII Okręg. W sierpniu 1847 r. w związku z reorganizacją tej instytucji, Hieronim Wołowski został mianowany przez Namiestnika Królestwa na posadę klasy VII radcy prawnego Zarządu tegoż Okręgu, z zastrzeżeniem noszenia munduru klasy VIII przez lat trzy ${ }^{72}$. Dla Hieronima, wychowanego wśród spraw transportu towarów kupca Wołowskiego, problematyka komunikacji pozostawała żywym zagadnieniem, tym bardziej, że jego młodszy brat Franciszek był kupcem w Płocku ${ }^{73}$. Należy nadmienić, że przedsiębiorcą przodującym w inwestowaniu $\mathrm{w}$ transport wodny i publiczny transport lądowy był znany w rodzinie Wołowskich Piotr Steinkeller ${ }^{74}$. Przed przejściem na posadę do Zarządu Komunikacji Hieronim złożył rezygnację z funkcji adwokata przy Sądzie Apelacyjnym. Nie

68 Akt małżeństwa: Brześć Kujawski, 2/1837, https://genealogiawarchiwach.pl/\#query.query=2\%2 52F1837\&query.city=Brze $\% 25 \mathrm{C} 5 \% 259 \mathrm{~B} \% 25 \mathrm{C} 4 \% 2587+$ Kujawski\&query.suggestion=false\&query. thumbnails $=$ false \&query.facet $=$ true $\&$ query.sortMode $=$ DEFAULT $\&$ modal $=253050841 \&$ goComments=false\&searcher=big (12.05.2019).

69 W. Witkowski, Komisja Rządowa Sprawiedliwości w Królestwie Polskim, Lublin 1986, s. 184.

70 Wiadomości, „Gazeta rządowa Królestwa Polskiego”, nr 222 z 5 X 1839r., s.1700; Wiadomości, „Gazeta rządowa Królestwa Polskiego", nr 197 z 7 IX 1841 r., s. 1549; W. Witkowski, Komisja..., op. cit. s. 243: patron przy Trybunale Cywilnym - obrońca przy Trybunale Cywilnym.

71 A. Suligowski, op. cit., poz. 548, s. 33.

72 Wiadomości, „Gazeta rządowa Królestwa Polskiego”, nr 174 z 10 VIII 1847 r., s. 1288. Klasa urzędnicza była określona stosownie do ukazu z 23.05.1836 r. dotyczącego hierarchii urzędniczej w Cesarstwie Rosyjskim, przyp. aut.

73 Akt zgonu: Płock, par. rzym.kat. św. Bartłomieja, 122/1850, Archiwum Państwowe w Płocku.

74 R. Kołodziejczyk, Steinkeller Piotr Antoni, [w:] Polski Słownik Biograficzny, red. J. Tazbir, t. XLIII/3, Warszawa 2005, s. 336-342. 
wiadomo, czy odejście z zawodu adwokata było konsekwencją osobistej decyzji o włączeniu się w rozwój komunikacji, czy wprowadzenia rosyjskiego Kodeksu Kar Głównych i Poprawczych ${ }^{75}$, czy też może chęci zatrudnienia się na etacie gwarantującym emeryturę lub pojawienie się problemów zdrowotnych.

Hieronim Wołowski zmarł w 1848 r. Na pogrzeb Hieronima, który odbywał się na Cmentarzu Powązkowskim dnia 1 lipca 1848 r., zapraszała pozostała żona wraz z sześciorgiem dzieci ${ }^{76}$. Dzieci miały wiek od 4 do 14 lat. Najmłodszy był Władysław Wołowski (trzech imion: Władysław Andrzej Józef) urodzony w Warszawie w $1843 \mathrm{r}^{77}$. Trochę starszy od niego był Bronisław Wołowski (trzech imion: Piotr Bronisław Jan) urodzony też w Warszawie w $1842 \mathrm{r}^{78}$ Zgodnie z cytowanym aktem urodzenia, ojcem chrzestnym Piotra Bronisława Jana był Piotr Steinkeller.

Balbina nie tylko w Brześciu angażowała się w życie całej rodziny. Już na początku 1838 r. wystąpiła w parze z Janem Wołowskim, stryjem Hieronima, asystując przy chrzcie Marianny Kazimiery Kozickiej, siostrzenicy męża ${ }^{79}$. Później, dzięki przykładowi sukcesów Hieronima, udało się jej namówić siostrę Annę, aby jej rodzina przeniosła się do Warszawy, gdzie szwagier został asesorem Sądu Poprawczego. Na początku 1844 r. oboje Grodeccy wzięli udział w chrzcie Władysława Wołowskiego: Józef jako ojciec chrzestny, Anna - jako asystentka matki chrzestnej ${ }^{80}$. Cztery lata później Józef Grodecki zgłaszał w parafii św. Andrzeja śmierć Hieronima ${ }^{81}$.

W międzyczasie zmarł ojciec Balbiny. Zgodnie z aktem zgonu Jan Nelski zmarł w Brześciu w 1846 r. scharakteryzowany jako „obrońca w Sądzie Pokoju obywatel tutejszy lat sześćdziesiąt trzy liczący, niewiadomych stawającym z imienia rodziców, mąż dawniej zmarłej Apolonii z Zgliczyńskich, pozostawiwszy jedyne trzy córki: Eleonorę zamężną Święcicką w Nowejwsi w Płockiem, Balbinę zamężną Wołowską i Annę z męża Grodecką w Warszawie zamieszkałe". Świadkami zejścia Jana Nelskiego byli Franciszek Zgliczyński asesor w Sądzie Policji Poprawczej 50 lat liczący i Maciej Kopczyński komornik okręgu brzeskiego mający lat 42, obaj w Brześciu zamieszkali ${ }^{82}$.

75 E. Kaczyńska, op. cit., s. 45.

76 Akt zgonu: Warszawa, św. Andrzej, 322/1848, op. cit.; Nekrolog Hieronima Wołowskiego: https://wielcy.pl/wgm/?m=NG\&t=PN\&n=sw.467624.

77 Akt urodzenia: Warszawa, Nawiedzenie NMP, 16/1844, http://metryki.genealodzy.pl/metryka. php?ar=1\&zs=0160d\&sy=1844\&kt=1\&plik=015-018.jpg\#zoom=1\&x=956\&y=1680 (12.05.2019).

78 Akt urodzenia: Warszawa, Nawiedzenie NMP, 142/1842,http://metryki.genealodzy.pl/metryka. php?ar=1\&zs=0160d\&sy=1842\&kt=1\&plik=139-142.jpg\#zoom=1\&x=2372\&y=1677 (12.05.2019).

79 Akt urodzenia: Warszawa, Nawiedzenie NMP, 86/1838,http://metryki.genealodzy.pl/metryka.php?a$\mathrm{r}=1 \& \mathrm{zs}=0160 \mathrm{~d} \& \mathrm{sy}=1838 \mathrm{a} \& \mathrm{kt}=1 \& \mathrm{plik}=083-086 . j p g \# \mathrm{zoom}=1 \& \mathrm{x}=2748 \& \mathrm{y}=1735(12.05 .2019)$.

80 Akt urodzenia: Warszawa, Nawiedzenie NMP, 16/1844, op. cit.

81 Akt zgonu: Warszawa, św. Andrzej, 322/1848, op. cit.

82 Akt zgonu: Brześć Kujawski, 17/1846, https://genealogiawarchiwach.pl/\#query.query=17\%252 F1846\&query.city=Brze\%25C5\%259B\%25C4\%2587+Kujawski\&query.page=1\&query.suggestion $=$ false \&query.thumbnails $=$ false \&query.facet $=$ false \&query.sortMode=DEFAULT\&moda- 


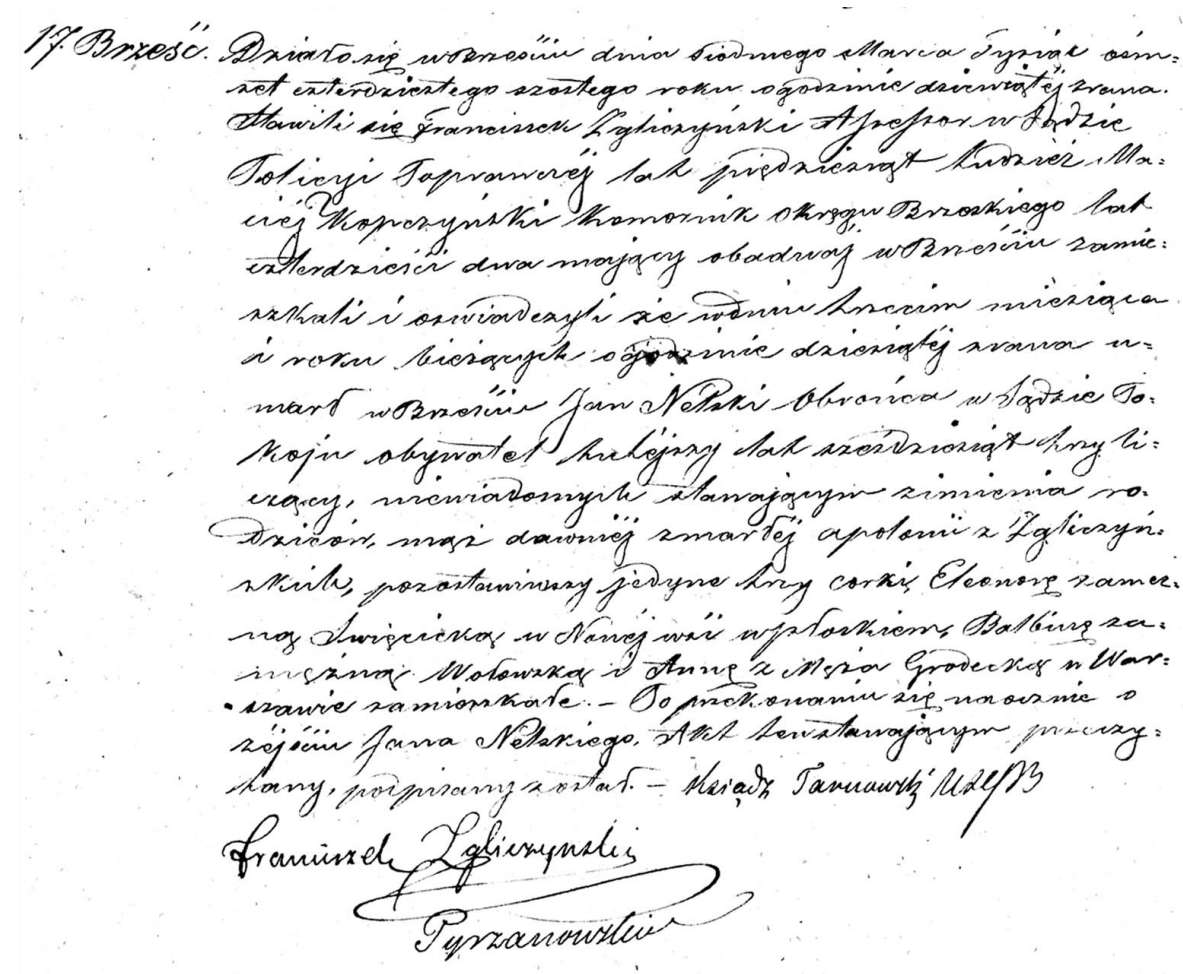

Skan aktu zgonu Jana Nelskiego.

Mimo zaawansowanego wieku Jan Nelski był obrońcą w sądzie pokoju, tak jak ćwierć wieku wcześniej, gdy spisywano akt urodzenia jego najmłodszego dziecka, Jana Aleksandra. Nelski był niezastąpiony z racji znajomości języka rosyjskiego, a w czasach jego późnej działalności tylko sędziowie pokoju byli zwolnieni z obowiązku władania tym językiem ${ }^{83}$. Żona wnuka Eleonory Święcickiej $^{84}$, z pochodzenia Rosjanka dobrze zorientowana w realiach społecznych Cesarstwa Rosyjskiego mówiła, że Nelscy byli znanym w Rosji rodem tatarskich kupców. Tatarzy byli muzułmanami. Przynależność Jana Nelskiego do mniejszości wyznaniowej potwierdza akt urodzenia jego syna, Jana Aleksandra Nelskiego, sporządzony przez księdza Antoniego Jabłońskiego jako urzędnika stanu cywilnego gminy brzeskiej. Nie ma tam wzmianki o chrzcie nowo narodzonego ${ }^{85}$. Syn Jana Nelskiego nie był chrześcijaninem. Na przykład w XIX w. na odległym

l=258099787\&goComments=false\&searcher=big (15.05.2019). We wszystkich wcześniejszych wpisach do ksiąg par. Brześć nazwiska lub imiona kobiet z rodziny Jana Nelskiego są pisane błędnie.

83 W.Witkowski, Komisja..., op. cit., s. 185.

84 J. E. Utkin, Wspomnienie o Witoldzie Święcickim. Czasy do 1944 roku, „Miscellanea Historico-Iuridica" 2017, nr XVI, z. 2, s. 216.

85 Akt urodzenia: Brześć Kujawski, par. rzym.-kat., 60/1821, Archiwum Państwowe w Toruniu, Oddział we Włocławku. 
od Kujaw terenie zróżnicowanych etnicznie guberni litewskich wyznanie dzieci ze związków tatarsko-polskich zależało od płci: syn był chowany w wierze ojca, córka - $\mathrm{w}$ wierze matki, przy czym było to rozwiązanie aprobowane przez muftich. Podobnie, córki Jana Nelskiego były katoliczkami. Świadkiem, który potwierdził w akcie urodzenia, że Jan Aleksander był synem Jana Nelskiego i Apolonii ze Zgliczyńskich był Augustyn Zgliczyński, obywatel w Brześciu zamieszkały.

Świadkowie podpisani na aktach stanu cywilnego dotyczących Nelskiego i jego najbliższych, pochodzili z rodziny żony lub zięcia albo też byli pracownikami lokalnych instytucji wymiaru sprawiedliwości. Otoczenie Jana Nelskiego było więc ograniczone do kręgu rodzinno-zawodowego, w Brześciu nie było diaspory, do której by należał.

\section{Spadkobiercy postaw i profesji Hieronima}

Podsumowując życiorys Hieronima można stwierdzić, że był powstańcem i prawnikiem. Przed śmiercią zapewnił rodzinie środki na życie, lecz była to egzystencja na skromnym poziomie. Świadczą o tym dane ze spisu mieszkańców: wdowa Balbina Wołowska utrzymywała się z funduszy własnych i mieszkała w Warszawie przy ul. Dzikiej 2322 w kamienicy, której właścicielem był Wolf Blumberg. Pod tym samym adresem mieszkał szwagier Balbiny Józef Grodecki, asesor kolegialny $^{86}$. Lokalizacja była mało elegancka, gdyż wówczas ul. Dzika sąsiadowała z kolektorem miejskich ścieków. Starsze dzieci Hieronima dorosły i pozakładały rodziny. Dwaj młodsi synowie, Bronisław i Władysław, odebrali jakieś wykształcenie, lecz nie pokończyli żadnych studiów. W szczególności żaden z synów Hieronima nie został prawnikiem, co było chyba poniżej aspiracji wdowy.

Młodsi synowie Hieronima walczyli w powstaniu styczniowym. Bronisław Wołowski napisał, że walczył jako „prosty żołnierz i podoficer w powstaniu 1863/64 r., dowodził następnie oddziałkiem strzelców pieszych. Organizator wojskowy powiatu rawskiego, pomocnik organizatora województwa mazowieckiego", którego potem zastąpi ${ }^{87}$. Władysław Wołowski napisał jedynie, że w latach 1863-1864 brał udział w 14-miesięcznej kampanii przeciw Rosjanom ${ }^{88}$. Po upadku powstania obaj bracia wyemigrowali do Francji.

W 1865 r. Balbina namówiła siostrę Eleonorę, aby wraz z mężem, Janem Stanisławem Święcickim i trójką uczących się dzieci przeniosła się do Warszawy. Balbina, której ojciec i mąż pracowali w sądach, przekonała Święcickich do

86 Skorowidz mieszkańców miasta Warszawy z przedmieściami na rok 1854. Warszawa 1854, s. 96, 372; Wykaz właścicieli domów s. 20, ibidem.

87 B. Wołowski, Z pamiętnika tułacza. Legion Polski we Francji w 1870-1871 roku, Lwów 1873, s. 102.

88

L. Wołowski, Corps franc des Vosges. Souvenirs, Paris 1871, s. 4. 
skierowania synów na studia prawnicze. Jan Święcicki, siostrzeniec urodzony w roku śmierci Hieronima, ukończył studia na Wydziale Prawa Imperatorskiego Uniwersytetu Warszawskiego. W Płocku w 1881 r. otworzył kancelarię adwokacką, a w latach 1917-1923 był prezesem Sądu Okręgowego w Płocku ${ }^{89}$. Młodszy siostrzeniec, Ludwik Święcicki po skończeniu pierwszego kursu na Wydziale Prawa, wyjechał na studia ekonomiczne za granicę ${ }^{90}$.

\section{Bibliografia}

\section{Literatura}

Gerber R., Studenci Uniwersytetu Warszawskiego 1808-1831. Stownik biograficzny, Wrocław 1977.

Jeske-Choiński T., Neofici polscy, Sandomierz 2017 (reprint wydania Warszawa 1904).

Kaczyńska E., Ludzie ukarani. Więzienia i system kar w Królestwie Polskim 1815-1914, Warszawa 1989.

Karpińska M., Senatorowie, posłowie i deputowani Księstwa Warszawskiego i Królestwa Polskiego, Warszawa 2002.

Kędzierski T., Proces „dyktatora Nocy Listopadowej” - Piotra Wysockiego, „Palestra” 1977, nr 21/11(239).

Kołodziejczyk R., Steinkeller Piotr Antoni, [w:] Polski Stownik Biograficzny, red. J. Tazbir, t. XLIII/3, Warszawa 2005, s. 336-342.

Papierowski A.J., Stefański J., Płocczanie znani i nieznani. Słownik biograficzny, Płock 2002, s. 597.

Pędowski K., Wołowski Jan Tadeusz, [ w:] Słownik biograficzny adwokatów polskich, t. 1, Warszawa 1883, s. 480-481.

Pol K., Poczet prawników polskich, wyd. 2 przejrzał i uzupełnił A. Redzik, Warszawa 2011.

Romański J., Wołowski Hieronim, [w:] Słownik biograficzny adwokatów polskich, t. 1, Warszawa 1983, s. 477-478.

Skorowidz mieszkańców miasta Warszawy z przedmieściami na rok 1854, Warszawa 1854.

Sługocki L., Łabęcki Antoni, [w:] Stownik biograficzny adwokatów polskich, t. 1, Warszawa 1881, s. 230-233.

Suligowski A., Bibliografia prawnicza polska XIX i XX wieku, Warszawa 1911.

Syga T., Szenic S., Maria Szymanowska i jej czasy, Warszawa 1960.

Szenic S., Cmentarz Powazkowski 1790-1850. Zmarli i ich rodziny, Warszawa 1979.

Taras A., Anatomia nienawiści. Stosunki polsko-rosyjskie XVIII-XX w., Warszawa 2015.

89 A.J. Papierowski, J. Stefański, op. cit., s. 597.

90 J.E. Utkin, op. cit., s. 215. 
Utkin J.E., Wspomnienie o Witoldzie Święcickim. Czasy do 1944 roku, „Miscellanea Historico-Iuridica” 2017, nr XVI, z. 2.

Witkowski W., Komisja Rządowa Sprawiedliwości w Królestwie Polskim, Lublin 1986.

Witkowski W., Aleksander This i Jan Kanty Wołowski wybitni prawnicy Królestwa Polskiego, Lublin 2001.

Wołowski B., Z pamiętnika tułacza. Legion Polski we Francji w 1870-1871 roku, Lwów 1873.

Wołowski L., Corps franc des Vosges. Souvenirs, Paris 1871.

\section{Gazety codzienne}

Wiadomości, „Gazeta rządowa Królestwa Polskiego”, nr 222 z 5 X 1839r., s.1700.

Wiadomości, „Gazeta rządowa Królestwa Polskiego”, nr 197 z 7 IX 1841 r., s. 1549.

Wiadomości, „Gazeta rządowa Królestwa Polskiego”, nr 174 z 10 VIII 1847 r., s. 1288.

\section{Źródła archiwalne}

Archiwum Państwowe w Płocku, zespół: akta stanu cywilnego par. rzym. - kat. św. Bartłomieja w Płocku.

Archiwum Państwowe w Toruniu, Oddział we Włocławku, zespół: akta stanu cywilnego par. rzym. - kat. Brześć Kujawski.

\section{Strony internetowe}

Akt zgonu: Warszawa, ASC Cyrkuł IV, 156/1808,https://szukajwarchiwach.pl/72/186/0//3/skan/full/3gRPVgLVOLmk7IihjwXzfw (12.05.2019).

Akt zgonu: Warszawa, św. Jan, 357/1831,https://szukajwarchiwach.pl/72/161/0/-/6/skan/ full/yDM4UFgefsK_L2rJwC6e5g (12.05.2019).

Akt małżństwa: Brześć Kujawski, 60/1832, https://genealogiawarchiwach.pl/\#query. query $=60 \% 252 \mathrm{~F} 1832 \&$ query.city $=$ Brze $\% 25 \mathrm{C} 5 \% 259 \mathrm{~B} \% 25 \mathrm{C} 4 \% 2587+$ Kujaw ski\&query.page $=1 \&$ query.suggestion $=$ false \&query.thumbnails=false\&query. facet $=$ false\&query.sortMode=DEFAULT \&modal=256368355\&goComment $\mathrm{s}=$ false\&searcher $=$ big (12.05.2019).

Akt zgonu: Warszawa, św. Jan, 522/1832, http://metryki.genealodzy.pl/metryka.php?a$\mathrm{r}=1 \& \mathrm{zs}=0161 \mathrm{~d} \& \mathrm{sy}=1832 \& \mathrm{kt}=3 \&$ plik= 520-525.jpg\#zoom $=1 \& \mathrm{x}=563 \& \mathrm{xy}=$ (12.05.2019).

Akt zgonu: Warszawa, św. Andrzej,169/1835, http://metryki.genealodzy.pl/metryka. php?ar=1\&zs=0159d\&sy=1835\&kt=3\&plik=167-170.jpg\#zoom =1\&x=2627 $\& y=147$ (12.05.2019).

Akt zgonu: Warszawa, św. Andrzej, 179/1835, http://metryki.genealodzy.pl/metryka.php ?ar=1\&zs=0159d\&sy=1835\&kt=3\&plik=179-182.jpg\#zoom =1\&x=538\&y= 240 (12.05.2019).

Akt małżenstwa: Płock, 22/1836, https://szukajwarchiwach.pl/50/155/0/-/20/\#tabSkany (15.05.2019). 
Akt urodzenia: Warszawa, św. Andrzej, 333/1836, http://metryki.genealodzy.pl/metryka. php?ar=1\&zs=0159d\&sy=1836\&kt=1\&plik=331-334.jpg\#zoom=1\&x= 2639 $\& y=404$ (12.05.2019).

Akt mał̇̇eństwa: Brześć Kujawski, 2/1837,https://genealogiawarchiwach .pl/\#query. query $=2 \% 252$ F1837\&query.city=Brze $\% 25$ C5\%259B\%25C4\%2587+Kujawski\&query.suggestion=false\&query.thumbnails=false\&query.facet=true\&query. sortMode=DEFAULT\&modal=253050841\&goComments=false\&searche$\mathrm{r}=$ big $(12.05 .2019)$.

Akt zgonu: Warszawa, św. Andrzej,156/1837,http://metryki.genealodzy.pl/metryka.php? ar=1\&zs=0159d\&sy=1837\&kt=3\&plik=155-158.jpg\#zoom =1\&x=938\&y= 2331 (12.05.2019).

Akt urodzenia: Warszawa, Nawiedzenie NMP, 86/1838, http://metryki.genealodzy.pl/ metryka.php?ar=1\&zs=0160d\&sy=1838a\&kt=1\&plik=083-086.jpg\#zoom $=1 \& \mathrm{x}=2748 \& \mathrm{y}=1735(12.05 .2019)$.

Akt urodzenia: Warszawa, Nawiedzenie NMP, 881/1838, http://metryki.genealodzy.pl/ metryka.php?ar=1\&zs=0160d\&sy=1838a\&kt=1\&plik=879-882.jpg\#zoom= $1 \& \mathrm{x}=2512 \& \mathrm{y}=127$ (12.05.2019).

Akt urodzenia: 247/1840 Warszawa, św. Andrzej, 247/1840, http://metryki.genealodzy.pl/ metryka.php?ar=1\&zs=0159d\&sy=1840\&kt=1\&plik=247-250.jpg\#zoom=1 $\& \mathrm{x}=472 \& \mathrm{y}=175(12.05 .2019)$.

Akt urodzenia: Warszawa, św. Jan, 542/1841, http://metryki.genealodzy.pl/metryka. php?ar=8\&zs=9233d\&sy=135\&kt=3\&skan=539-542.jpg\#zoom $=1 \& \mathrm{x}=1675$ $\& y=1294(12.05 .2019)$.

Akt urodzenia: Warszawa, Nawiedzenie NMP, 142/1842, http://metryki.genealodzy.pl/ metryka.php?ar=1\&zs=0160d\&sy=1842\&kt=1\&plik=139-142.jpg\#zoom=1\& $\mathrm{x}=2372 \& \mathrm{y}=1677$ (12.05.2019).

Akt zgonu: Warszawa, św. Andrzej, 290/1842, http://metryki.genealodzy.pl/metryka. php?ar=1\&zs=0159d\&sy=1842\&kt=3\&plik=287-290.jpg\#zoom =1\&x=2830 $\& y=1668(12.05 .2019)$.

Akt zgonu: Warszawa, św. Aleksander, 334/1843, https://szukajwarchiwach.pl/72/162/0//21/skan/full/mxqt0W5gYehvn-QM0QRWxw (12.05.2019).

Akt urodzenia: Warszawa, Nawiedzenie NMP, 16/1844, http://metryki.genealodzy.pl/ metryka.php? ar=1\&zs=0160d\&sy=1844\&kt=1\&plik=015-018.jpg\#zoom =1\&x $=956 \& y=1680(12.05 .2019)$.

Akt zgonu: Brześć Kujawski, 17/1846, https://genealogiawarchiwach.pl /\#query.query $=17 \% 252$ F $1846 \&$ query.city=Brze $\% 25$ C5\%259B $\% 25$ C4\%2587+Kujawski\& query.page $=1$ \&query.suggestion $=$ false \&query.thumbnails $=$ false \&query.facet $=$ false\&query.sortMode $=$ DEFAULT\&modal $=258099787 \&$ goComments $=$ false\&searcher $=$ big (12.05.2019).

Akt zgonu: Warszawa, św. Andrzej, 322/1848,http://metryki.genealodzy.pl/metryka.php ?ar=1\&zs=0159d\&sy=1848\&kt=3\&plik=319-322.jpg\#zoom=1\&x=2667\&y= $1471(12.05 .2019)$. 
Nekrolog Hieronima Wołowskiego, [w:] M.J. Minakowski, Wielcy.pl (Wielka genealogia Minakowskiego), https://wielcy.pl/wgm/?m=NG\&t=PN\&n=sw.467624 (12.05.2019).

Adam Wołowski, [w:] M. J. Minakowski, Wielcy.pl (Wielka genealogia Minakowskiego), https://wielcy.pl/wgm/?m=NG\&t=PN\&n=sw.717949 (12.05.2019).

Jan Kanty Wołowski, [w:] M.J. Minakowski, Wielcy.pl (Wielka genealogia Minakowskiego), https://wielcy.pl/wgm/?m=NG\&t=PN\&n=sw.206242 (12.05.2019).

Karolina Emilia Wołowska, [w:] M.J. Minakowski, Wielcy.pl (Wielka genealogia Minakowskiego), https://wielcy.pl/wgm/?m=NG\&t=PN\&n=12.110.187 (12.05.2019).

Ludwik Wołowski, [w:] M.J. Minakowski, Wielcy.pl (Wielka genealogia Minakowskiego),https://wielcy.pl/wgm/?m=NG\&t=PN\&n=sw.164831 (12.05.2019).

Ludwika Nowopolski-Thisz h. Rycerzosław, [w:] M.J. Minakowski, Wielcy.pl (Wielka genealogia Minakowskiego), https://wielcy.pl/wgm/?m= NG\&t=PN\&n=sw.299167 (12.05.2019).

Zdzisław Antoni Jeziorański „Jan Nowak”, [w:] M.J. Minakowski, Wielcy.pl (Wielka genealogia Minakowskiego), https://wielcy.pl/wgm/?m=NG\&t=PN\&n=sw.155427 (12.05.2019).

Drugi Pułk Mazurów, https://pl.wikipedia.org/wiki/2_Pu\%C5\%82k_Mazur\%C3\%B3w (02.05.2019).

\section{STreszCZenie}

Kluczowa postać, Hieronim Wołowski, żyjący w latach 1806-1848 był prawnikiem, młodszym bratem mecenasa Jana Tadeusza Wołowskiego. Wywodzili się z rodziny kupieckiej. Dziadek Hieronima, Franciszek Wołowski, był ochrzczonym frankistą, kupcem korzennym, który miał swój sklep w Warszawie przy ul. Elektoralnej. Kupcem był również Józef, ojciec Hieronima, a także brat Hieronima Franciszek. Ci dwaj kupcy mieszkali na przemian w nadwiślańskich miastach: w Warszawie i Płocku. Młodzież z tej rodziny osobiście angażowała się w walkę z zaborcą, zarówno w okresie powstania listopadowego, jak i styczniowego. Większość powiązań rodzinnych Hieronima została rozwikłana na podstawie Wielkiej genealogii Minakowskiego. Szczególnie istotne okazały się informacje ze strony internetowej Adama Wołowskiego w edycji z 2018 r.

Wybór zawodu i późniejsza praca Hieronima w sądach nosiły ślad wpływu Jana Tadeusza. Znana kariera tego sławnego obrońcy została tu pokrótce przypomniana w połączeniu z jego dwoma związkami małżeńskimi. Pierwszą żoną Jana Tadeusza była Ludwika This, siostra Aleksandra, pierwszego bohatera książki Wojciecha Witkowskiego. Drugą żoną Jana Tadeusza - wdowca była Kazimiera Wołowska, młodsza siostra pianistki Marii Szymanowskiej, bohaterki książki Sygi i Szenica. Matka Kazimiery, Barbara z Wołowskich Wołowska, była siostrą ojca Jana Tadeusza.

Podgląd aktu zgonu Adama Wołowskiego, stryja Hieronima, pozwolił dokładniej ustalić rok urodzenia i zawód protoplasty rodu, Franciszka Wołowskiego, 
a w konsekwencji obalić pogląd o ojcostwie Franciszka Salomona Łukasza Wołowskiego, przywódcy warszawskich ochrzczonych frankistów.

Analiza powiązań rodziny od strony babki Hieronima, Teresy z Lanckorońskich Wołowskiej i porównanie ich z informacjami ze strony internetowej Jana Kantego Wołowskiego, pozwoliło na ustalenie pochodzenia jego żony Henrietty z Wołowskich primo voto Jeziorańskiej, a także na stwierdzenie, że znany cywilista Feliks Jeziorański był siostrzeńcem Jana Kantego Wołowskiego. Są to fakty genealogiczne, których nie uwzględnia nawet drugie wydanie Pocztu prawników polskich $X I X-X X$ w. Krzysztofa Pola.

Kariera zawodowa Hieronima Wołowskiego została przedstawiona na tle wydarzeń historycznych i dziejów jego rodziny. Kolejne szczeble tej kariery to studia, a po udziale w powstaniu listopadowym i krótkim okresie emigracji, praca inkwirenta przy Sądzie Policji Poprawczej, adwokatura i nominacja na patrona gubernialnego Trybunału Cywilnego, a po upływie dwóch lat - na adwokata Sądu Apelacyjnego. Ustąpienie z tego stanowiska wiązało się z mianowaniem na posadę radcy prawnego okręgowego Zarządu Komunikacji Lądowych i Wodnych. Podstawą opisu kariery prawniczej Hieronima była przede wszystkim notka biograficzna w słowniku Gerbera zweryfikowana wiadomościami z „Gazety Rządowej Królestwa Polskiego” oraz obie cytowane książki Wojciecha Witkowskiego. Zawodowej karierze Hieronima towarzyszyło małżeństwo z Balbiną Nelską.

U źródła zainteresowania tematyką opracowania występuje pokrewieństwo autorki z żyjącą w latach 1814-1903 żoną Hieronima Wołowskiego oraz pewna wiedza rodzinna, którą udało się uzupełnić. Weryfikacją i rozszerzeniem wiedzy rodzinnej poprzez poszukiwania genealogiczne i archiwalne przez witrynę Genealodzy. pl, która kierowała do dokumentów w odpowiednich serwisach genealogicznych, a także na podstawie portalu Marka Minakowskiego Wielcy.pl (Wielka genealogia Minakowskiego), przeprowadził Marek Utkin, brat autorki. Opisane powiązania w rodzinie Wołowskich były weryfikowane przez podgląd skanów aktów z ksiąg parafialnych Warszawy, Brześcia Kujawskiego i Płocka. Wymienieni w aktach stanu cywilnego świadkowie odzwierciedlają relacje w rodzinie. Rok urodzenia danego Wołowskiego był, w razie braku dostępu do odpowiedniego aktu, obliczany na podstawie innych dostępnych aktów stanu cywilnego, skorygowano też błędy w brzmieniu nazwiska teściowej Hieronima.

\section{SUMMARY}

\section{Descendants of Wołowski, the merchant - lawyers, insurgents in the 19th century}

The key figure, Hieronim Wołowski, who lived in the years 1806-1848 was a lawyer, the younger brother of the attorney Jan Tadeusz Wołowski. They came from a merchant 
family. Hieronim's grandfather, Franciszek Wołowski, was a baptized Frankist (Jacob Frank's follower), a spice merchant who had his shop in Warsaw at Elektoralna Street. Józef, the father of Hieronim, as well as Hieronim's brother Franciszek were also merchants. The two merchants lived alternately in cities situated on the Vistula bank: in Warsaw and in Płock. The youth from the family were personally engaged in the struggle with the Russian occupier, during both the November and January Uprisings. Most of Hieronim's family connections were unravelled thanks to Minakowski's Great Genealogy. Information available on the Adam Wołowski website as of 2018 turned out to be of particular importance.

The choice of profession and the later work of Hieronim in the courts were affected by Jan Tadeusz. The well-known career of this famous advocate is briefly recalled here in the context of his two marriages. The first wife of Jan Tadeusz was Ludwika This, Aleksander's sister, was the leading protagonist of Wojciech Witkowski's book. The second wife of Jan Tadeusz, widower, was Kazimiera Wołowska, younger sister of the pianist Maria Szymanowska, heroine of the book by Syga and Szenic. Kazimiera's mother, Barbara Wołowska née Wołowska, was the sister of Jan Tadeusz's father.

A preview of the death certificate of Adam Wołowski, Hieronim's uncle, enabled us to determine more precisely the year of birth and occupation of the family progenitor, Franciszek Wołowski, and consequently to rebut the view about the alleged fatherhood of Franciszek Salomon Łukasz Wołowski, leader of the baptized Frankists in Warsaw.

An analysis of family ties on the side of Hieronim's grandmother, Teresa Wołowska née Lanckorońska, and their comparison with information derived from the Jan Kanty Wołowski website, made it possible to determine the descent of his wife, Henrietta, from the Wołowski family primo voto Jeziorańska, as well as to find out that the well-known civilest, Feliks Jeziorański was a nephew of Jan Kanty Wołowski. These are genealogical facts, which are not even included in the second edition of the List of Polish Lawyers of the 19th -20th Century by Krzysztof Pol.

The professional career of Hieronim Wołowski is presented against the background of historical events and the history of his family. The further levels of his career are studied, and after participation in the November Uprising and a short period of emigration, he worked as an investigator at the Correctional Police Court as an advocate, and was appointed as the governorate patron of the Civil Tribunal, and after the lapse of two years he was promoted to the position of advocate of the Court of Appeal. He resigned from this position owing to his appointment as the legal adviser to the regional Board of Land and Water Transport. The basis for the description of Hieronim's legal career was primarily a biographical note in the Gerber dictionary checked against information from the "Governmental Gazette of the Kingdom of Poland" ("Gazeta Rządowa Królestwa Polskiego") and both above-quoted books by Wojciech Witkowski. Hieronim devoted himself both to his professional career and his marriage with Balbina Nelska. 
The author's interest in the subject of this study originates from her kinship with Hieronim Wołowski's wife, who lived in the years 1814 - 1903, and certain family knowledge that she managed to supplement. The information on family was verified and expanded through genealogical and archival searches on the Genealodzy.pl website, which has links to documents in relevant genealogical websites, as well as Marek Minakowski's portal Wielcy.pl (the Minakowski's Great Genealogy) carried out by Marek Utkin, the author's brother. The described connections in the Wołowski family were verified by viewing scans of entries in the church-books of Warsaw, Brześć Kujawski and Płock. The witnesses named in the civil status records reflect the family relationships. The year of Wołowski's birth was, in the absence of access to the relevant certificate, calculated on the basis of other available civil status records, and the misspelled surname of Hieronim's mother in-law was corrected. 